\title{
Dual-porosity modeling of groundwater recharge: testing a quick calibration using in situ moisture measurements, Areuse River Delta, Switzerland
}

\author{
Abdallah Alaoui · Werner Eugster
}

\begin{abstract}
A simple method for calibrating the dualporosity MACRO model via in situ TDR measurements during a brief infiltration run $(2.8 \mathrm{~h})$ is proposed with the aim of estimating local groundwater recharge (GR). The recharge was modeled firstly by considering the entire $3 \mathrm{~m}$ of unsaturated soil, and secondly by considering only the topsoil to the zero-flux plane $(0-0.70 \mathrm{~m})$. The modeled recharge was compared against the GR obtained from field measurements. Measured GR was $313 \mathrm{~mm}$ during a 1-year period (15 October 1990-15 October 1991). The best simulation results were obtained when considering the entire unsaturated soil under equilibrium conditions excluding the macropore flow effect $(330 \mathrm{~mm})$, whereas under non-equilibrium conditions GR was overestimated $(378 \mathrm{~mm})$.

Sensitivity analyses showed that the investigation of the topsoil is sufficient in estimating local GR in this case, since the water stored below this depth appears to be below the typical rooting depth of the vegetation and is not available for evapotranspiration. The modeled recharge under equilibrium conditions for the 0.7 -m-topsoil layer was found to be $364 \mathrm{~mm}$, which is in acceptable agreement with measurements.
\end{abstract}

Résumé Une méthode simple pour la calibration du modèle à double porosité MACRO par des mesures TDR in situ durant un bref essai d'infiltration $(2.8 \mathrm{~h})$ a été proposée pour l'estimation locale de la recharge de la nappe (RN). La RN a été d'abord simulée en tenant compte de toute la zone non saturée $(3 \mathrm{~m})$ et ensuite, en

Received: 4 March 2003 / Accepted: 17 July 2003

Published online: 17 September 2003

(C) Springer-Verlag 2003

\footnotetext{
A. Alaoui (

Soil Science Section, Department of Geography, University of Bern,

Hallerstrasse 12, 3012 Bern, Switzerland

e-mail: alaoui@giub.unibe.ch

Fax: +41-31-6318511

W. Eugster

Climatology and Meteorology Research Group,

Department of Geography,

University of Bern,

Hallerstrasse 12, 3012 Bern, Switzerland
}

considérant uniquement la couverture du sol entre zéro et le plan du flux nul $(0.70 \mathrm{~m})$. La RN simulée a été comparée à la $\mathrm{RN}$ observée. La RN mesurée durant une année (15 octobre 1990-15 octobre 1991) était de $313 \mathrm{~mm}$. Les meilleures simulations ont été obtenues en tenant compte de toute la zone non saturée sous les conditions d'équilibre excluant le flux préférentiel (330 mm). Sous les conditions de non équilibre, la RN a été surestimée $(378 \mathrm{~mm})$.

Les analyses de sensitivité ont montré que l'investigation de la couverture du sol est suffisante pour l'estimation locale de la RN du fait que l'eau traversant le plan du flux nul se trouverait sous la zone des racines et échapperait à l'évapotranspiration. La RN simulée sur les $0.70 \mathrm{~m} \mathrm{du}$ sol sous les conditions d'équilibre était de $364 \mathrm{~mm}$, ce qui est comparable aux mesures.

Resumen Se propone un método sencillo para calibrar el modelo de doble porosidad "MACRO" mediante medidas in-situ obtenidas por TDR durante un breve ensayo de infiltración (2,8 horas), con el objetivo de estimar la recarga local al acuífero. Ésta ha sido modelada de dos formas: considerando los $3 \mathrm{~m}$ de suelo no saturado y empleando sólo desde la capa superior hasta el plano de flujo nulo (de 0 a $0,70 \mathrm{~m}$ ). Se compara la recarga modelada con la recarga local medida en campo, la cual fue de $313 \mathrm{~mm}$ durante un ciclo anual (del 15 de octubre de 1990 al 15 de octubre de 1991). Las mejores simulaciones corresponden a la hipótesis de columna entera no saturada en condiciones de equilibrio, excluyendo el efecto de macroporos (valor de $330 \mathrm{~mm}$ ), mientras que el resultado obtenido para condiciones de no equilibrio en la recarga local está sobreestimado (378 mm).

Los análisis de sensibilidad muestran que la investigación del horizonte superior del suelo es suficiente para estimar la recarga local en este caso, ya que el agua almacenada por debajo de esta profundidad parece estar fuera del alcance típico de las raíces de la vegetación y no puede ser evapotranspirada. La recarga modelada en condiciones de equilibrio para la capa superior de $0,70 \mathrm{~m}$ de espesor es de $364 \mathrm{~mm}$, valor aceptable respecto a las medidas. 
Keywords Groundwater recharge - Dual-porosity modeling · Unsaturated zone · Porous media · Neuchâtel · Switzerland

\section{Introduction}

There are a number of factors that affect the recharge of groundwater. In a natural catchment, hydraulic conductivity and porosity of the soil, rainfall, the slope of the water bearing layer, and soil moisture content are among the most relevant ones. However, besides climate, the hydraulic conductivity and porosity of the soil have the strongest influence ( $\mathrm{Su}$ 1994). Other control variables affecting recharge are soil type (increasing clay content decreases recharge; e.g., Athavale et al. 1980; Edmunds et al. 1992) and vegetation characteristics (longer growing season or deeper rooting depths decrease recharge; e.g., Nulsen and Baxter 1986; Zhang et al. 1999).

The rate of aquifer recharge is one of the factors that are most difficult to measure when evaluating groundwater resources and requires expensive monitoring installations. Recharge cannot be measured directly, so its quantification is often error-prone, requiring validation by comparisons among various methods (Lerner et al. 1990). Rate estimates may be based on either hydrometeorologic, potentiometric, or surface-water flow methods (Sophocleous 1991). The most common hydrometeorological method is the fluid-mass-balance approach (Rushton and Ward 1979), which calculates land-surface water budgets by subtracting measured or estimated evapotranspiration plus runoff from precipitation. The most common potentiometric approach employs aquifer saturated-volume fluctuations, which assumes a close relationship of water-table fluctuations with recharge (Van Tonder and Kirchner 1990; Sophocleous 1991). Flow-based estimates commonly employ integral hydrograph separation of streamflow or springflow time series.

Watershed (rainfall/runoff) modeling is used to estimate recharge rates over large areas. Singh (1995) reviewed many watershed models which generally provide recharge estimates as a residual term in the waterbudget equation (Arnold et al. 1989; Leavesley and Stannard 1995; Hatton 1998). The minimum recharge rate that can be estimated is controlled by the accuracy with which the various parameters in the water budget can be measured and by the time scale that is considered. Modeling is useful in various ways (Walker et al. 2002): (1) to objectively analyze climatic data in order to determine in which areas certain land-use features will always be ineffective, (2) to analyze which factors are important in determining recharge, so that results can be transferred from one field area to another with only limited additional field work, and (3) to estimate longterm impacts from short-term field trials by allowing for the natural climate variability. Recharge along preferential flow paths has received considerable attention in the past decade with an increasing number of studies verifying the significance of the process and attempting

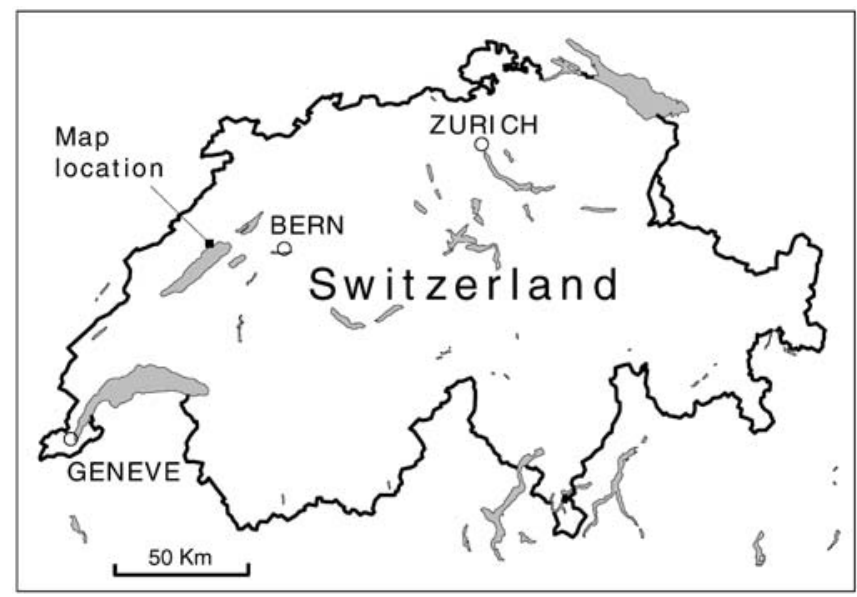

Fig. 1 Map location; Areuse River delta, Neuchâtel, Switzerland

to quantify its relative contribution to the groundwater body. Recharge may occur in either of two categories: rapid (macropore) recharge through extremely conductive vadose channels; or slow (matrix) recharge, through granular or fractured media (Stephens 1996). The literature also indicates that in some cases local groundwater recharge models that ignore the possibility of such phenomena may be highly misleading. An overview of the topic is given by Stephens (1994).

Jarvis (1994) developed a physically based model (MACRO) of water and solute transport in macroporous soil. The model divides the total soil properties into two components, macropores and micropores, and can be run in either one or two domains.

The aim of this study was to reproduce the groundwater recharge observed during one year in an experimental site near the city of Neuchâtel, Switzerland (Fig. 1), using the widely used dual-porosity MACRO model (Jarvis 1994). For this, a quick calibration method was to be tested using in situ TDR measurements made during a brief infiltration run $2 \mathrm{~m}$ from the experimental site with the help of a simple equation for estimating evapotranspiration (Primault 1962; see also MdaghriAlaoui and Eugster 2001). The recharge was then simulated over the $3 \mathrm{~m}$ unsaturated soil during a oneyear period. Alternatively, the simulation was restricted to the upper most $0.70-\mathrm{m}$ soil layer in order to investigate whether knowledge of the upper soil conditions were sufficient for obtaining satisfactory results of total recharge.

\section{Materials and Methods}

\section{Site Description}

Measurements were carried out from 15 October 1990 to 15 October 1991, at the experimental site located $430 \mathrm{~m}$ a.s.l. along the orographical left side of the Areuse River on its delta, $200 \mathrm{~m}$ away from the shore of lake Neuchâtel. The Areuse River delta has been a focus of several 
Table 1 Texture and bulk density $\left(\rho_{\mathrm{b}}\right)$ of the soil

\begin{tabular}{llllll}
\hline Depth $(\mathrm{m})$ & \multicolumn{2}{l}{ Particle size distribution (\% by weight) } & \\
\cline { 2 - 5 } & \multicolumn{2}{l}{ Diameter class $(\mathrm{mm})$} & & \\
\cline { 2 - 5 } & $<0.002$ & $0.002-0.05$ & $0.05-2.0$ & $>2.0$ & \\
\hline $0-0.36$ & 35 & 24 & 31 & 10 & 1.32 \\
$0.36-0.44$ & 23 & 28 & 47 & 2 & 1.42 \\
$0.44-0.70$ & 12 & 31 & 56 & 1 & 1.36 \\
$0.70-0.80$ & 3 & 7 & 23 & 67 & $/$ \\
\hline
\end{tabular}

geological and hydrogeological studies in the past decades (Burger 1980; Mdaghri-Alaoui 1990). The aquifer has a complex and horizontally heterogeneous geological structure, being covered by approximately $3 \mathrm{~m}$ of unsaturated soil composed of a 0.2-0.3 m humus layer overlaying a sandy loam. The highly permeable coarse sediments vary locally from sandy gravel to gravel. Additional data from the Areuse River delta aquifer and its geometry were obtained from detailed geophysical investigation in conjunction with a log lithostratigraphic study of the region's wells and piezometers (MdaghriAlaoui et al. 1993). The aquifer shows lithological heterogeneities with a complex deltaic structure. It consists of sandy gravel having an average thickness of about $20 \mathrm{~m}$. The substratum of the aquifer is mostly composed of silty clay. The water table varied between 2.7 and $3.2 \mathrm{~m}$ in depth. In the investigated area, the vegetation consists of short-cut grassland.

Variations in water storage were obtained from weekly measurements with a neutron probe. Hydraulic gradients obtained by pressure measurements were used to identify periods with significant infiltration and to locate the zeroflux plane separating deep drainage and evapotranspiration. A particle size analysis was carried out because it was expected that the zero-flux plane that was seen in the hydraulic gradient data coincides with a textural change in the soil profile.

\section{Soil Texture}

The soil is composed of recent fluvial deposits from the Areuse River. The Areuse delta deposits fill a depression in the basement of the Jura foothills beginning at $\approx 2 \mathrm{~km}$ distance from the measuring site. The quaternary deposits to both sides of the recent river delta are a mixture of fluvio-glacial and fluvial deposits from the last two ice ages (Würm and Riss).

The soil horizon between 0 and $0.36 \mathrm{~m}$ is a clay loam soil containing gravel and few rocks (Table 1). The soil $\mathrm{pH}$ is $\approx 7$ and the porosity varies between 47 and $54 \%$. Organic matter varies between 4 and $5 \%$ by mass. Between 0.36 and $0.70 \mathrm{~m}$ the soil is composed of sandy clay loam $(0.36-0.44 \mathrm{~m})$ and sandy loam $(0.44-0.70 \mathrm{~m})$ with a very low content of coarse material (Table 1). The porosity varies between 46 and $51 \%$, and the $\mathrm{pH}$ ranges between 7 and 8 . The soil below $0.70 \mathrm{~m}$ consists of coarse material, primarily gravel and stones, and the soil matrix

Hydrogeology Journal (2004) 12:464-475 is composed of fine sand. Thus, in summary, three primary interfaces were found which separate distinct soil horizons: the first is at a depth of 0.36 , the second around 0.44 , and the third and most important for the hydrology of the experimental site at $0.70 \mathrm{~m}$.

\section{Methods}

Water balance measurements

The experimental site for the long-term measurements consists of a well of $1.5 \mathrm{~m}$ diameter and $3.3 \mathrm{~m}$ depth which was excavated to allow the horizontal insertion of tensiometers and their monitoring, and a pressure probe for water table measurements.

Precipitation was measured with a Hellmann-type gauge with a resolution of $0.5 \mathrm{~mm}$. Evapotranspiration was modeled with two approaches, an empirical approach by Primault (1962) and the more widely known and frequently used mechanistic approach by Penman-Monteith (Monteith and Unsworth 1990). Most of the meteorological data needed in both evapotranspiration models were obtained locally from a standard three-cup anemometer and wind vane at $3.5 \mathrm{~m}$ height, and a combined air temperature and relative humidity probe (Rotronic, Switzerland, type MP-100F) mounted in a white radiation shield at $2.0 \mathrm{~m}$ height. Duration of sunshine and global radiation data were obtained from an automatic weather station run by MeteoSwiss near Neuchâtel, $6 \mathrm{~km}$ to the north of the field site. It should be noted that the empirical Primault method was used to estimate evapotranspiration from cut grassland in Switzerland at elevations between 300 and 1,200 m a.s.l.

The vertical profile of the pressure head was measured with tensiometers (SenSym, type LX06005G) at depths of $0.55,1.02,1.54$ and $2.07 \mathrm{~m}$. Hydraulic gradients were measured from 15 October 1990 to 12 August 1991. After this period, the tensiometer measurements had to be discarded due to deterioration of the instruments which was influencing the measurements. However, since these measurements were not used for computing the annual water balance, this did not affect the overall goal of this project.

A Bell and Howell type BHL 4003 pressure probe was installed in the saturated zone at $3.65 \mathrm{~m}$ depth to automatically determine changes in the groundwater table. A model 503DR neutron moisture probe (Campbell Pacific Nuclear, Martinez, California, USA) was used to measure changes in soil moisture. The probe was capable of monitoring moisture to a depth of $3.5 \mathrm{~m}$ below the surface. The moisture gauge contained a fast radioactive (americium 241-beryllium) neutron source. The neutron probe was field calibrated against gravimetric soil water samples from 0 to a depth of $3.60 \mathrm{~m}$. The samples were taken every $0.20 \mathrm{~m}$. Different calibration relationships were grouped to account for two soil layers, $0.10-0.70 \mathrm{~m}$, and $0.70-3.60 \mathrm{~m}$ (Table 2). The sampled volumetric water content varied from 34 to $46 \%$ in the topsoil and from 8 to $11 \%$ in the subsoil. The residual standard deviation varied from 0.023 in the topsoil to $0.024 \mathrm{~m}^{3} \mathrm{~m}^{-3}$ in the subsoil. 
Table 2 Fitted parameters of the calibration of the neutron probe for two soil layers $(0.00-0.70$ and $0.70-3.60 \mathrm{~m})$

\begin{tabular}{|c|c|c|c|c|c|}
\hline Depth (m) & $\begin{array}{l}\text { Number of } \\
\text { observations }\end{array}$ & $\begin{array}{l}\text { Slope of the } \\
\text { regression line }\end{array}$ & $\begin{array}{l}\text { Intercept of the } \\
\text { regression line }\end{array}$ & $\begin{array}{l}\text { Coefficient of } \\
\text { determination }\left(\mathrm{r}^{2}\right)\end{array}$ & $\mathrm{SD}\left(\mathrm{m}^{3} \mathrm{~m}^{-3}\right)$ \\
\hline $0.00-0.70$ & 5 & 0.00303 & 9.17 & 0.98 & 0.023 \\
\hline $0.00-3.60$ & 13 & 0.00110 & 1.13 & 0.70 & 0.024 \\
\hline
\end{tabular}

For replication and verification of the vertical soil moisture profile, an access tube (MS 63, brass with $40 \mathrm{~mm}$ inner diameter and $2 \mathrm{~mm}$ tube strength) was inserted into the ground for the neutron probe at a distance of $1 \mathrm{~m}$ from the tensiometer profile. The time integration of neutron counts was $32 \mathrm{~s}$ and measurements were carried out at $0.10 \mathrm{~m}$ depth intervals once per week to a depth of $3.6 \mathrm{~m}$. All instruments listed above were attached to a data logger (Data Taker, model DT100) and average values recorded every $30 \mathrm{~min}$.

\section{The empirical evapotranspiration model by Primault}

Primault (1962) proposed an empirical approach to estimate evapotranspiration from short-cut grassland in Switzerland at elevations between 300 and 1,200 m a.s.l.,

$E=c\left[A \frac{103-r \mathrm{H}}{100}\left(t_{\mathrm{s}}+2 t_{\mathrm{p}}\right)+B\right]$

where total evapotranspiration $E(\mathrm{~mm})$ during a period of $t_{\mathrm{p}}$ days is a function of the average relative humidity $r \mathrm{H}$ $(\%)$ of this period, and the total duration of sunshine $t_{\mathrm{s}}(\mathrm{h})$. Three parameters correct for variations in the altitude ( $A$ and $B$ ) and the season $(c)$. Variations in the altitude are given by:

$A=-0.12+0.00306 h-2.83 \cdot 10^{-6} h^{2}+9.45 \cdot 10^{-10} h^{3}$

where $h$ is the altitude in $\mathrm{m}$ a.s.l. This parameter reflects that increasing precipitation at increasing altitudes is expected to lead to increasing evapotranspiration when the solar forcing and atmospheric conditions are kept constant. The value of $A$ varies between 0.57 and 1.11 . The height-dependent offset $B$ can be approximated by:

$B=0.5387-0.0003263 h-6.525 \cdot 10^{-7} h^{2}$

It varies between 0.38 at $300 \mathrm{~m}$ and -0.79 at $1,200 \mathrm{~m}$ and only plays a minor role. In contrast, the seasonal variation $c$ significantly influences $E$ as is described by:

$$
\begin{gathered}
c=-0.5068 \cdot \sin \left(\frac{2 \pi}{365} D O Y+0.5593\right)-0.0711 . \\
\cdot\left(\frac{4 \pi}{365} D O Y+0.6112\right)+0.6271
\end{gathered}
$$

where $D O Y$ is day of year. The coefficient $c$ adjusts the evapotranspiration estimates for temperature effects. Such a correction is necessary since air temperature (or net radiation) is not a driving variable in this empirical model. Primault (1962) only published tables and figures of the coefficients. Equations (2), (3) and (4) were therefore fitted to Primault's graphical data using the least-squares technique. The average relative humidity $r H$ for a period of several days is not an actual physical measure, but instead a statistical value that is easily derived from standard meteorological measurements. Unweighted averaging of the half-hourly measurements was used to obtain the average $r \mathrm{H}$ for all weekly periods. Primault's (1962) model is supposed to be used at this or longer time steps.

\section{Estimating groundwater recharge}

The water budget of a soil column was determined with a combined experimental and modeling approach to quantify the components of the water budget on a weekly basis. The budget equation

$P-E \pm \Delta S-R=0$

was used, where $P$ is precipitation, $E$ is evapotranspiration, $\Delta S$ is the change of the water stored in the soil column between the groundwater table and the surface, and $R$ is recharge to the groundwater table. All units are in $\mathrm{mm}$ water column. Evapotranspiration accounts for 62 $65 \%$ of water budget, depending on the method (MdaghriAlaoui and Eugster 2001). Therefore, $R$ is sensitive to any errors that are made in estimating evapotranspiration. The disadvantage of the Penman-Monteith approach is that it only applies to active vegetation and is therefore not necessarily the best estimate during winter conditions with snow and frozen ground.

In contrast, Primault's (1962) empirical fit for seasonality takes this into account for Switzerland where the equation was developed, and is therefore also applicable during winter conditions. However, the Primault method requires cross-validation with an independent method to ascertain that the empirical parameters are valid at a given experimental site. Despite these important differences in approaches, at our site, the Primault method gave excellent agreement of weekly evaporation sums with the well-known Penman-Monteith approach compared over the period of one year $\left(r^{2}=0.97\right.$; Fig. 2$)$. The total evapotranspiration of the 12 months measuring period as was estimated with the Primault approach was 3\% less than the one obtained with the Penman-Monteith approach. From this it can be concluded that the Primault method is a valuable and simple approach for longer-term studies where only standard meteorological measurements are available without energy balance data, the availability of which is essential for the use of the Penman-Monteith approach, and which is one of the most limiting factors for its application. Therefore, without direct measurements of evapotranspiration (e.g., using the 


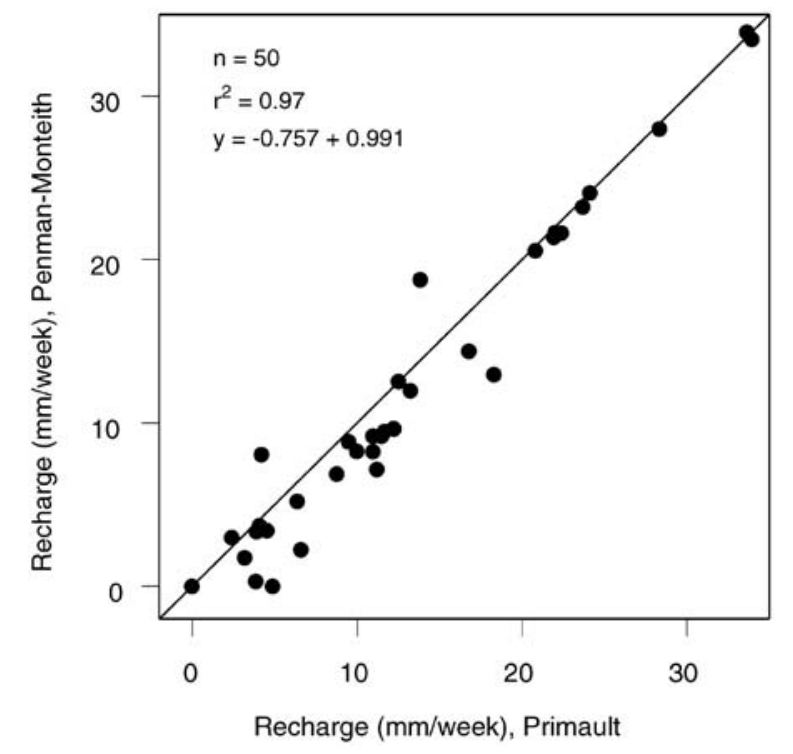

Fig. 2 Regression between the weekly recharge obtained with the empirical approach by Primault (1962) and the recharge obtained by the more physically based Penman-Monteith approach

eddy covariance method) it cannot be conclusively said whether the Penman-Monteith method is a good reference for such a comparison during those periods, since low evapotranspiration values were mostly found during the cold season where vegetation is not very active. For the sake of simplicity, the Primault method was used in the simulations. We assume in this study that all water that passes the rooting zone has escaped the direct influence of evapotranspiration and could recharge the groundwater reservoir. In this one-dimensional simplification it is assumed that lateral flow is negligible. Both surface runoff and subsurface lateral flows can be assumed to be close to zero due to the fact that the slope of the Areuse delta plain is only $1 \%$ at the surface, and the slope of the water table, as measured in the direction heading towards the lake of Neuchâtel, varies between 1 and 6\%o. Surface runoff is not normally observed, even during heavy showers.

The procedure to estimate groundwater recharge contained two steps:

1. Firstly, the water balance over one year (15 October 1990-15 October 1991) was evaluated at the experimental site via weekly measurements of soil moisture using a neutron probe, and by estimating evapotranspiration from standard meteorological data.

2. Secondly, a pit of $1.20 \mathrm{~m}^{2}$ and $1 \mathrm{~m}$ depth $(2 \mathrm{~m}$ from the experimental site) was excavated in situ to allow the horizontal insertion of four TDR-probes in the soil profile. Water was applied at the soil surface within $2.8 \mathrm{~h}$ as described in the next section. Soil moisture was measured continuously with the TDR-probes. The soil moisture measurements were used to calibrate the model at depths of $0.10,0.30,0.46$ and $0.58 \mathrm{~m}$. Then, the MACRO model was validated against measured soil moisture and groundwater recharge during a 1year period at the experimental site.

\section{Brief in situ irrigations}

Water was sprinkled on the soil surface over $1 \mathrm{~m}^{2}$ above the TDR probes with a rainfall simulator at a rate of $q=6.68 \times 10^{-6} \mathrm{~m} \mathrm{~s}^{-1}$ and a duration of $t=10120 \mathrm{~s}$. Volumetric soil moisture $\theta\left(\mathrm{m}^{3} \mathrm{~m}^{-3}\right)$ was measured with a TDR-system. TDR-probes were horizontally inserted at four depths. A wave-guide consisted of a pair of rods of stainless steel with $6 \mathrm{~mm}$ diameter and $0.3 \mathrm{~m}$ length. In the application of TDR for soil water measurements, the Tektronix $1502 \mathrm{~B}$ is the source of a very short rise time pulse which is applied to a probe. It also collects a signal which is a reflection of the applied pulse and displays the reflection as a waveform. The wave-guides were multiplexed with an SDMX50 50W coax multiplexer, which was controlled by a Campbell $21 \mathrm{X}$ datalogger. The TDR system was calibrated according to Roth et al. (1990) who separated the impact of the wave-guide geometry from the soil properties - such as bulk density and the content of clay and organic matter-on the dielectric constant. The limit of significant differences among individual measurements with the same wave-guide was assessed at $0.002\left(\mathrm{~m}^{3} \mathrm{~m}^{-3}\right)$. TDR measurements were repeated every $300 \mathrm{~s}$.

\section{MACRO Model}

MACRO is a mechanistic dual-porosity model applicable to water movement and solute transport in soils. The model is briefly introduced here. For more details, see Jarvis (1994). The total porosity is partitioned at a boundary water content/potential into macropores and micropores. Each domain is characterized by a degree of saturation, a conductivity and a flux, while interaction terms account for convective and diffusive exchange between flow domains. Water movement in the micropores is calculated with the Richards' equation including a sink term to account for root water uptake. The soil hydraulic properties in the micropores are described by the functions of Brooks and Corey (1964) and Mualem (1976):

$\psi_{\mathrm{mi}}=\psi_{\mathrm{b}} S_{\mathrm{mi}}^{-1 / \lambda}$

$K_{\mathrm{mi}}=K_{\mathrm{b}} S_{\mathrm{mi}}^{\mathrm{n}+2+2 / \lambda}$

$S_{\mathrm{mi}}=\frac{\theta_{\mathrm{mi}}-\theta_{\mathrm{r}}}{\theta_{\mathrm{b}}-\theta_{\mathrm{r}}}$

where the subscript 'mi' refers to micropores, $\theta_{\mathrm{b}}\left(\mathrm{m}^{3} \mathrm{~m}^{-3}\right)$, $\psi_{\mathrm{b}}(\mathrm{m})$ and $K_{\mathrm{b}}\left(\mathrm{m} \mathrm{s}^{-1}\right)$ are the water content, pressure head and hydraulic conductivity at the boundary between micro- and macropores, respectively, $\theta_{\mathrm{mi}}$ is the current water content, $\lambda(-)$ is the pore size distribution index, $\theta_{\mathrm{r}}\left(\mathrm{m}^{3} \mathrm{~m}^{-3}\right)$ is the residual water content, $S_{\mathrm{mi}}\left(\mathrm{m}^{3} \mathrm{~m}^{-3}\right)$ is the degree of saturation and $n(-)$ is the tortuosity factor. 
Water flow in the macropores is calculated with an approach derived from Darcy's law assuming a unit hydraulic gradient and simple power law function to represent the unsaturated hydraulic conductivity:

$q_{\mathrm{ma}}=\left(K_{\mathrm{s}}-K_{\mathrm{b}}\right)\left(\frac{\theta_{\mathrm{ma}}}{\theta_{\mathrm{s}}-\theta_{\mathrm{b}}}\right)^{n *}$

where the subscript 'ma' refers to macropores, $\theta_{\mathrm{ma}}\left(\mathrm{m}^{3} \mathrm{~m}^{-3}\right)$ is the macropore water content, $\theta_{\mathrm{s}}\left(\mathrm{m}^{3} \mathrm{~m}^{-3}\right)$ is the saturated water content, $K_{\mathrm{s}}\left(\mathrm{m} \mathrm{s}^{-1}\right)$ is the saturated hydraulic conductivity and $n^{*}(-)$ reflects pore size distribution and tortuosity in the macropore system.

When using two flow domains, the surface boundary condition prescribed in MACRO partitions the net rainfall $R$ in a given time interval $\Delta \mathrm{t}$ into an amount taken up by micropores $I_{\mathrm{mi}}$ and an excess amount of water which flows into macropores $I_{\max }$ :

$I_{\mathrm{mi}}=\left\{\begin{array}{c}R, \quad R \leqslant I_{\max } \\ I_{\max }, R>I_{\max }\end{array}\right\}$

$I_{\mathrm{ma}}=\left\{\begin{array}{cc}0, & R \leqslant I_{\max } \\ R-I_{\mathrm{mi}}, R>I_{\max }\end{array}\right\}$

where $I_{\max }$ is the infiltration capacity of the micropores approximated by:

$I_{\max }=\Delta z_{1}\left(\theta_{\mathrm{b} 1}-\theta_{1}\right)+\Delta t q_{\text {out }(1)}$

where the subscript 1 refers to the surface soil layer, $q_{\text {out(1) }}$ is the water flow rate out of this layer, $\Delta \mathrm{z}$ is the layer thickness and $\Delta \mathrm{t}$ is the time step.

Various alternative options for the bottom boundary condition are available in the model (i.e., constant hydraulic gradient, zero flux, constant potential with or without inflow of water at the bottom boundary, or lysimeter with free drainage). Boundary conditions used in this study are specified in the following section.

The rate of lateral water exchange from macropores to micropores $S_{\mathrm{w}}$ is also treated as a first-order approximation to a diffusion-type process (Booltink et al. 1993). Assuming that gravity has negligible influence, $S_{\mathrm{w}}$ is given by:

$S_{\mathrm{w}}=\left[\frac{3 D_{\mathrm{w}} \gamma_{\mathrm{w}}}{d^{2}}\right]\left(\theta_{\mathrm{b}}-\theta_{\mathrm{mi}}\right)$

where $D_{\mathrm{w}}\left(\mathrm{m}^{2} \mathrm{~s}^{-1}\right)$ is an effective diffusivity, $\gamma_{\mathrm{w}}(-)$ is a scaling factor and $d(\mathrm{~mm})$ is an effective diffusion pathlength which controls the mass exchange between the domains (Jarvis 1994). The effective water diffusivity is assumed to be given by:

$D_{\mathrm{w}}=\left(\frac{D_{\theta \mathrm{b}}+D_{\theta \mathrm{mi}}}{2}\right) S_{\mathrm{ma}}$

where $D_{\theta \mathrm{b}}$ and $D_{\theta \mathrm{mi}}$ are the water diffusivities at the boundary water content and the current micropore water content, respectively. Using the Mualem/Brooks-Corey model for soil hydraulic properties, $D_{\theta \mathrm{mi}}$ is given by:
$D_{\theta \mathrm{mi}}=\frac{K_{\mathrm{b}} \psi_{\mathrm{b}} S_{\mathrm{mi}}^{\mathrm{n}+1 / \lambda+1}}{\lambda\left(\theta_{\mathrm{b}}-\theta_{\mathrm{r}}\right)}$

while $D_{\theta \mathrm{b}}$ is given by setting $S_{\mathrm{mi}}$ in Eq. (14) to unity.

If the micropores become over-saturated (i.e., $\theta_{\mathrm{mi}}>\theta_{\mathrm{b}}$ ), then the excess water is routed instantaneously into the macropores and the second term on the right-hand side of Eq. (12) is adjusted accordingly.

Root water uptake is calculated from evaporative demand, root distribution, and soil water content using the simple empirical 'sink function' described by Jarvis (1989). In this model, it is assumed that the ratio between actual and potential root water uptake $\left(E_{\mathrm{a}} / E_{\mathrm{r}}\right)$ varies as a function of a dimensionless water stress index $\omega^{*}$. The threshold value of the water stress index $\omega^{*}$ c (termed the 'root adaptability factor') governs the degree to which the crop adjusts to stress in one part of the root system by increasing uptake from other parts where conditions may be more favorable (Jarvis 1989; Jarvis and LeedsHarrison 1990).

The stress index is calculated by combining two functions describing the distribution of roots and water content in the soil profile:

$\omega^{*}=\sum_{i=1}^{i=k} r_{i} \omega_{i}$

where $k$ is the number of soil layers in the profile containing roots and $r_{\mathrm{i}}$ and $\omega_{\mathrm{i}}$ are the proportion of the total root length and a water stress 'reduction factor' in layer $i$, respectively.

Root length is assumed to be distributed logarithmically with depth (Feddes et al. 1974; Gerwitz and Page 1974):

$r_{\mathrm{i}}=\varsigma\left(\frac{\Delta z_{\mathrm{i}}}{z_{\mathrm{r}}}\right) e^{-\varsigma\left(\frac{z_{\mathrm{m}(\mathrm{i})}}{z_{\mathrm{r}}}\right)}$

where $\Delta z_{\mathrm{i}}$ and $z_{\mathrm{m}(\mathrm{i})}$ are the thickness and mid-point depth below the soil surface of layer $i$, respectively, $z_{\mathrm{r}}$ is the root depth and $\zeta$ is an empirical root distribution parameter. Finally, the total water uptake is distributed within the root depth according to the stress in each layer. The water uptake sink $S_{\mathrm{r}}$ is therefore given by:

$S_{\mathrm{r}}=\left(\frac{E_{\mathrm{a}}}{\Delta z_{\mathrm{i}}}\right)\left(\frac{r_{\mathrm{i}} \omega_{\mathrm{i}}}{\omega^{*}}\right)$

If the model is run in two flow domains, the calculated root water uptake is assumed to be preferentially satisfied from water stored in the macropores. Any excess demand is then satisfied from water stored in the micropores.

Initial conditions, boundary conditions and discretization The model was first calibrated via short water infiltration made in situ. The obtained calibrated parameters were used to simulate the recharge (1) over $3 \mathrm{~m}$ unsaturated soil and (2) over $0.7 \mathrm{~m}$ unsaturated soil during one year. In all simulations, the soil profile was represented with 15 soil slabs, with the top 9 slabs representing the $0.70 \mathrm{~m}$ of 
Table 3 Model input parameters: soil hydraulic properties

\begin{tabular}{clllllll}
\hline Depth (cm) & \multicolumn{7}{l}{ Parameters $^{\mathrm{a}, \mathrm{b}}$} \\
\cline { 2 - 7 } & $\begin{array}{l}\theta_{\mathrm{s}} \\
\left(\mathrm{m}^{3} \mathrm{~m}^{-3}\right)\end{array}$ & $\begin{array}{l}\theta_{\mathrm{b}} \\
\left(\mathrm{m}^{3} \mathrm{~m}^{-3}\right)\end{array}$ & $\begin{array}{l}\theta_{\mathrm{r}} \\
\left(\mathrm{m}^{3} \mathrm{~m}^{-3}\right)\end{array}$ & $\begin{array}{l}\psi_{\mathrm{b}} \\
(\mathrm{cm})\end{array}$ & $\begin{array}{l}\lambda \\
(-)\end{array}$ & $\begin{array}{l}K_{\mathrm{s}} \\
\left(\mathrm{mm} \mathrm{h}^{-1}\right)\end{array}$ & $\begin{array}{l}K_{\mathrm{b}} \\
\left(\mathrm{mm} \mathrm{h}^{-1}\right)\end{array}$ \\
\hline $0-8$ & 0.50 & 0.47 & 0 & 20 & 0.05 & 200 & 0.3 \\
$8-28$ & 0.50 & 0.46 & 0 & 20 & 0.05 & 50 & 0.3 \\
$28-36$ & 0.50 & 0.49 & 0 & 20 & 0.05 & 49 & 0.3 \\
$36-70$ & 0.45 & 0.43 & 0 & 15 & 0.07 & 30 & 0.5 \\
$>70$ & 0.45 & 0.44 & 0 & 15 & 0.07 & 90 & 0.5 \\
\hline
\end{tabular}

a Parameters: $\theta_{\mathrm{s}}$ is the saturated water content, $K_{\mathrm{s}}$ is the saturated hydraulic conductivity

${ }^{\mathrm{b}}$ Derived by calibration: $\theta_{\mathrm{b}}$ is the boundary water content, $\psi_{\mathrm{b}}$ is boundary tension, $\lambda$ is the pore size distribution index and $K_{\mathrm{b}}$ is the boundary hydraulic conductivity, $\theta_{\mathrm{r}}$ is the residual water content which was set to zero in the simulation
Fig. 3 Calibration of the MACRO model using in situ TDR measurements at four depths in the topsoil during a brief infiltration experiment
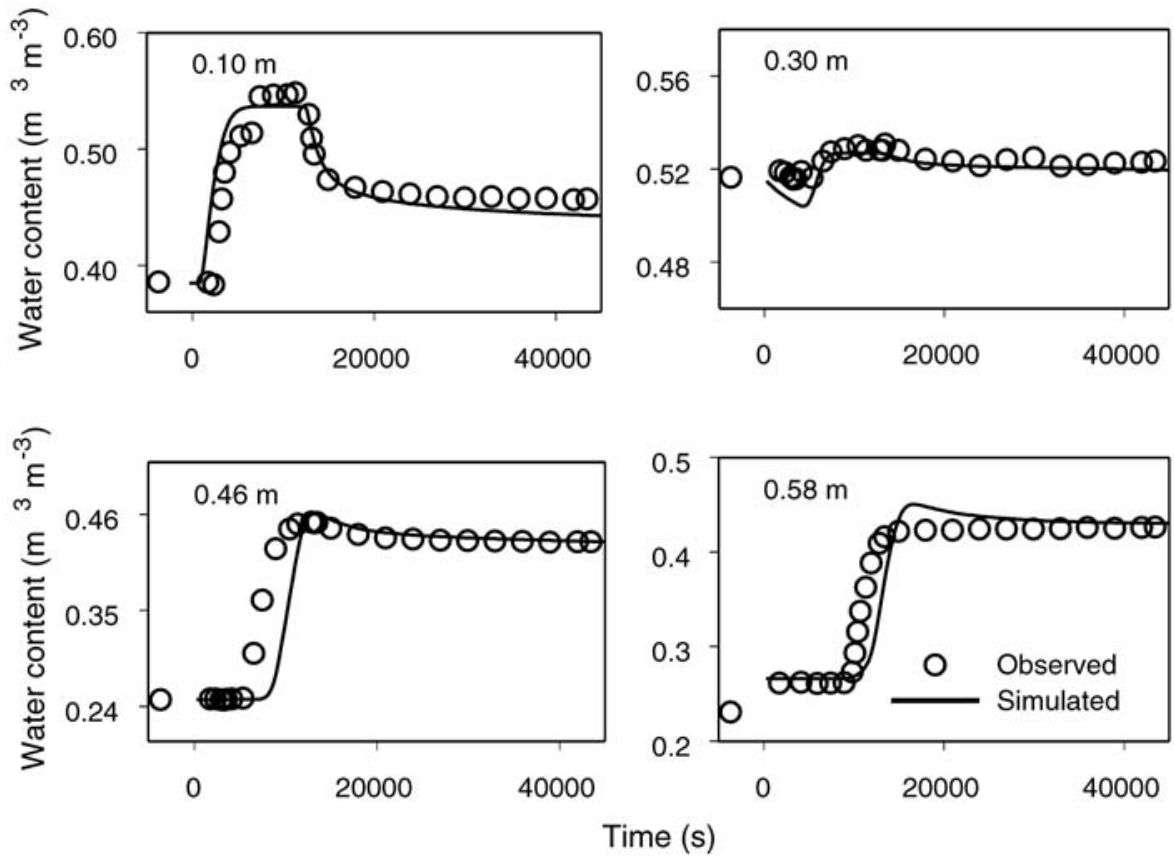

topsoil and the remaining 6 slabs for soil layer between 0.70 and $3.0 \mathrm{~m}$ depth. This discretization was chosen according to the soil properties (i.e., texture). When considering the simulation in the topsoil, we assume that water reaching the bottom of the model is no longer available for evapotranspiration and will eventually reach the water table at or below $3 \mathrm{~m}$. In this study, a constant hydraulic gradient was assumed as the boundary condition at the base of the soil profile and was derived from the pressure measurements (Mdaghri-Alaoui and Eugster 2001). The initial water content in the profile was determined from the TDR profile measurements before the start of the in situ infiltration and from the first measurements of water content for the calibration and validation, respectively.

\section{Measured parameters}

The measured saturated water content $\theta_{\mathrm{s}}$ was $50 \%$ between 0 and $0.36 \mathrm{~m}, 45 \%$ between 0.36 and $0.70 \mathrm{~m}$ depth (Table 3). The measured saturated hydraulic conductivity $K_{\mathrm{s}}$ was set to the average value measured in each horizon i.e., $200 \mathrm{~mm} \mathrm{~h}^{-1}$ between 0 and $0.08 \mathrm{~m}$, $50 \mathrm{~mm} \mathrm{~h}^{-1}$ between 0.08 and $0.38 \mathrm{~m}, 30 \mathrm{~mm} \mathrm{~h}^{-1}$ between 0.38 and $0.52 \mathrm{~m}$, and $90 \mathrm{~mm} \mathrm{~h}^{-1}$ between 0.52 and $0.70 \mathrm{~m}$ depth.

\section{Parameter estimation}

In this study, model input parameter values were obtained by a combination of direct measurements and model calibration using the objective statistical criteria discussed in the following section.

Saturated hydraulic conductivity was determined on samples of undisturbed soil with a diameter of $55 \mathrm{~mm}$ and length of $42 \mathrm{~mm}$ taken at $50 \mathrm{~mm}$ depth increments throughout the soil profile. Saturated hydraulic conductivity was determined with a constant head permeameter (Klute and Dirksen 1986). The bulk density, porosity and saturated water content were deduced from the weight of saturated and dried soil samples. The boundary hydraulic conductivity $K_{\mathrm{b}}$, boundary water content $\theta_{\mathrm{b}}$, boundary soil water pressure head $\Psi_{\mathrm{b}}$, and pore size distribution index $\lambda$ were derived by calibration (Table 3 ) by running the 
MACRO model in inverse modeling mode with the soil moisture profile data measured with TDR probes as independent input (Fig. 3). To reduce the degree of freedom of this calibration run, $\theta_{\mathrm{r}}$ was set to zero throughout the soil profile, a value found by Saxena et al. (1994) for a similar soil type. The maximum rooting depth was fixed at $0.60 \mathrm{~m}$ based on field observations. The best estimate obtained in this way for the fraction of roots that was able to maintain optimum uptake rates up to a water tension of $10 \mathrm{~m}$, was $60 \%$. This estimate appears to be in reasonable agreement with what would be estimated from Jackson et al.'s (1996) typical root distributions.

\section{Model calibration}

The MACRO model was calibrated using in situ TDR measurements from four depths $(0.10,0.30,0.46$ and $0.58 \mathrm{~m}$ ) for the topsoil simulation. TDR measurements were made during the brief infiltration run and the model was then validated during one year against measured data of water content and recharge from the experimental site. Below $0.70 \mathrm{~m}$, the parameters were calibrated using the soil moisture measured with the neutron probe at the experimental site. In this case, the model was validated against recharge data.

The calibrated parameters were obtained using a gridsearch technique (see for instance Duan et al. 1992). The optimal parameter combination was identified by the minimum of the root mean square error under two constraints: the slope of the regression between predicted and measured values should be in the range of 0.9 to 1.1 and the coefficient of residual mass in the range of 0.001 to -0.001 . The calibration was carried out using a preliminary version of a software program designed to calibrate the MACRO model (Acutis et al. 2001), enabling the automatic execution of the model for each point of the chosen grid and the evaluation of several objective functions under user-defined constraints. The coefficient of residual mass CRM is defined as (Loague and Green 1991):

$$
\mathrm{CRM}=\frac{\sum_{i=1}^{n} M_{\mathrm{i}}-\sum_{i=1}^{n} E_{\mathrm{i}}}{\sum_{i=1}^{n} M_{\mathrm{i}}}
$$

where $M_{\mathrm{i}}$ represents the measured values, $E_{\mathrm{i}}$ represents the estimated values and $n$ is the number of observations. A fairly good fit of model predictions to the measured water content was observed highlighted by the very small values of CRM ( 0.0135 for $0.10 \mathrm{~m}$ depth, 0.0059 for 0.30 , 0.017 for 0.46 , and 0.0052 for 0.58 ).

\section{Results and Discussion}

\section{Experimental Results}

Three horizons were distinguished in the unsaturated zone with respect to their specific hydrological responses to

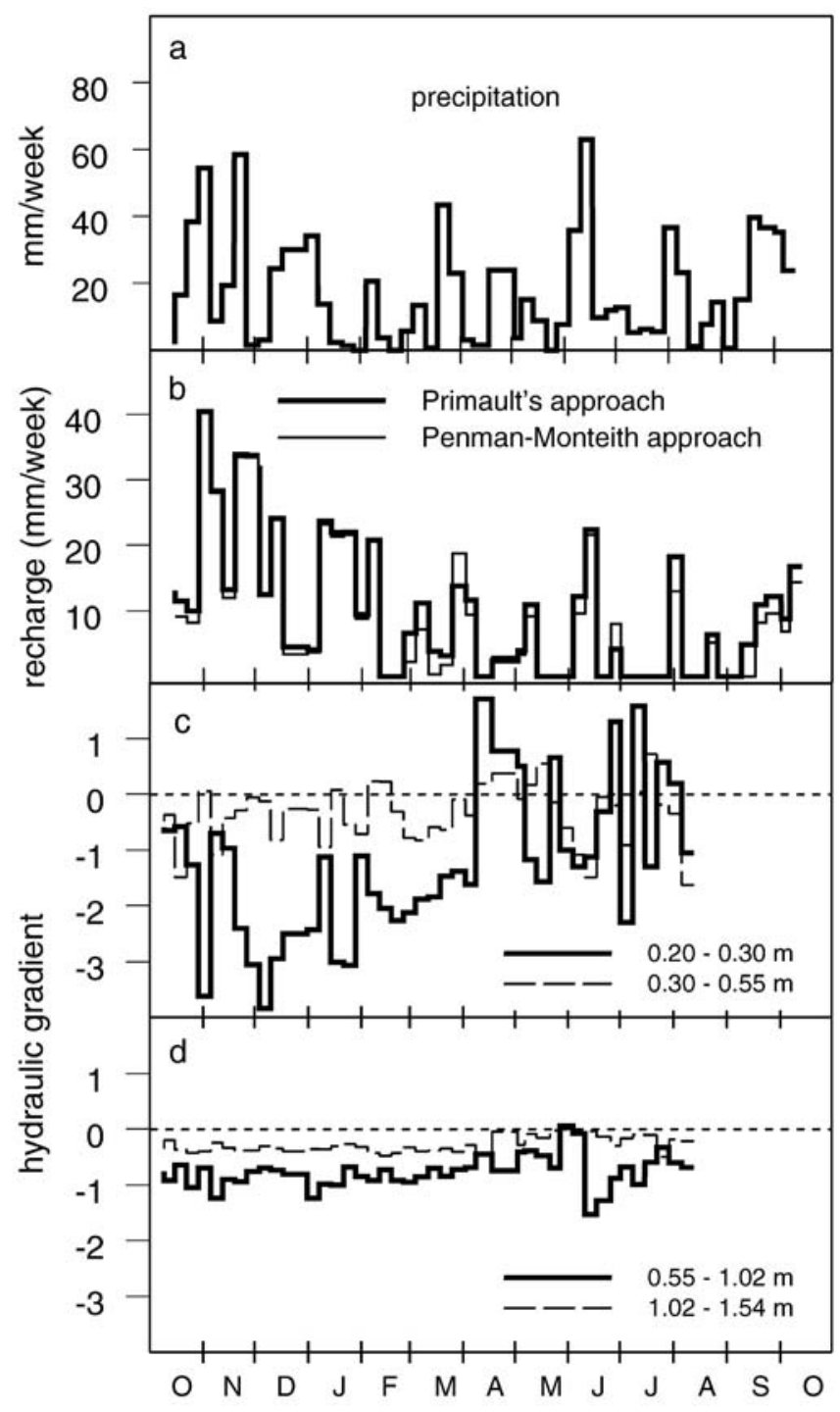

Fig. 4 Water balance of the Areuse delta between 15 October 1990 and 15 October 1991 (weekly sums or averages): a precipitation sum; b recharge estimated by two approaches; $\mathbf{c}$ and $\mathbf{d}$ time course of the hydraulic gradient of four soil layers between 15 October 1990 and 15 August 1991

external factors (Mdaghri-Alaoui and Eugster 2001). In the uppermost $0.70 \mathrm{~m}$, which is composed of fine material, the variations of water storage correlate highly with the precipitation input. In the subsoil $(2.4-3.0 \mathrm{~m})$, the water storage variations during winter is highly influenced by the height of the groundwater table. Between these horizons, the water storage variation during winter is highly correlated with the precipitation which has no influence in summer. The zero-flux plane was localized at a depth of $0.70 \mathrm{~m}$, showing that the water losses below this depth contribute to recharging the groundwater body (Fig. 4c, d). This finding is consistent with the particle size distribution in the soil profile which showed two zones with differing texture. In fact, the lower zone below $0.7 \mathrm{~m}$ is composed of coarser gravel 


\begin{tabular}{lllll}
\hline$\Delta \mathrm{z}(\mathrm{m})^{\mathrm{a}}$ & Flow regime & Simulated GR $(\mathrm{mm})$ & Regression & $\mathrm{r}^{2}$ \\
\hline 3.00 & One flow domain & 330 & $\mathrm{y}=1.13 \mathrm{x}-18.25$ & 0.984 \\
3.00 & Two flow domains & 378 & $\mathrm{y}=1.16 \mathrm{x}+12.88$ & 0.98 \\
0.70 & One flow domain & 364 & $\mathrm{y}=0.957 \mathrm{x}+45.43$ & 0.97 \\
0.70 & Two flow domains & 394 & $\mathrm{y}=1.014 \mathrm{x}+45.21$ & 0.966 \\
\hline
\end{tabular}

${ }^{\mathrm{a}} \Delta \mathrm{z}(\mathrm{m})$ is the thickness of soil considered in the simulation, the correlation regression is established between observed $(\mathrm{x})$ and simulated recharge $(\mathrm{y})$

than the upper zone. This textural examination of the soil indicates that the water stored below this interface is not used for evapotranspiration and appears to be below the typical rooting depth of the vegetation $(0.4-0.6 \mathrm{~m})$.

The annual-actual evapotranspiration was estimated to be 532 and $564 \mathrm{~mm}$ according to the Primault and Penman-Monteith methods, respectively; the difference was 3\% (Fig. 2), indicating that Primault's (1962) empirical approach is an easy-to-use and efficient method for estimating evapotranspiration in Switzerland.

The total precipitation measured during our observation period was $865 \mathrm{~mm}$. About one third (33-36\%, according to the Penman-Monteith and the Primault approach, respectively) of the annual precipitation contributes to groundwater recharge. Evapotranspiration accounts for $65 \%$ according to Primault's approach and $62 \%$ according to the Penman-Monteith approach. The remaining $2 \%$ were found in the change of the water stored in the soil $(\Delta S)$. However, it should be noted that the year of our measurements was moderately dry and only yielded $89 \%$ of the long-term annual precipitation as measured during the 30-year period 1961-1990.

During the summer period of 1 April-31 August, $306 \mathrm{~mm}$ of precipitation were collected, which corresponds to $35 \%$ of total precipitation collected during the whole experimental period. The evapotranspiration loss computed with the Primault and Penman-Monteith approach corresponds to 135 and $134 \%$, respectively, of the precipitation collected in summer, whilst the fraction of precipitation available for groundwater recharge is 35 and $33 \%$, respectively, which corresponds to roughly $12 \%$ of total rainfall measured during the full period. Thus, evapotranspiration revealed to be the dominant component in the water balance of the Areuse River delta during the warm season.

\section{Modeling Results}

The parameter set derived from the in situ calibration experiment (Fig. 3) was used to predict water content at depths of 0.30 and $0.50 \mathrm{~m}$ and recharge (1) over the entire $3 \mathrm{~m}$ of unsaturated soil and (2) in the topsoil between 0 and $0.70 \mathrm{~m}$, during a period of one year $(15$ October 1990-15 October 1991).

\section{Simulations over the entire unsaturated zone}

The best simulations for this period and over the entire unsaturated zone were obtained under equilibrium conditions indicating the absence of dominant preferential flow: the correlation between observed and simulated

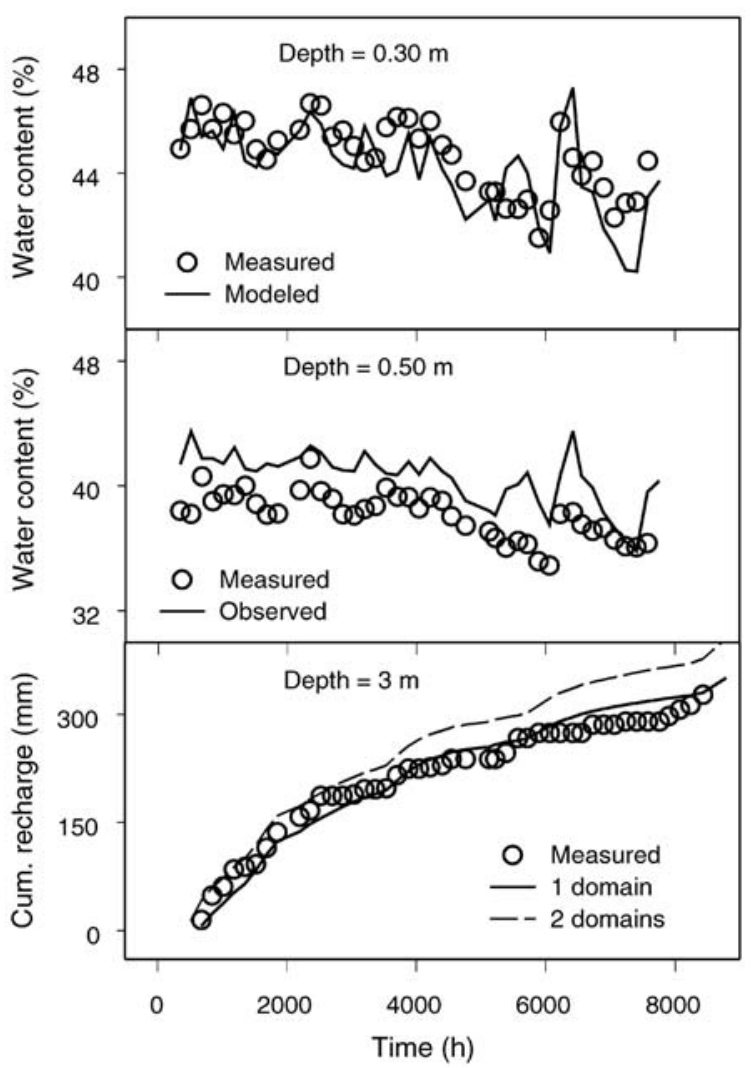

Fig. 5 Validation of the MACRO model with the water content measurements and groundwater recharge

recharge under equilibrium conditions was $\mathrm{r}^{2}=0.984$ (Table 4). The discrepancies between observed and simulated water content were more pronounced in summer, which may be due to the lateral flow during that season, a factor that is not considered by the model. Lenses of fine material are frequently found in this soil, indicating the potential relevance of lateral flows. The correlation between observed and simulated water content is quite good (Fig. 5) at depths of 0.30 (CRM=0.0120) and $0.50 \mathrm{~m}(\mathrm{CRM}=0.0628)$ except for cold periods with snow cover in February 1991, which delayed the increase of water content by roughly three weeks towards the end of February and beginning of March 1991. The recharge quantified from the measurements was $313 \mathrm{~mm}$. Comparatively, under non-equilibrium conditions, the recharge simulated by the model was $378 \mathrm{~mm}$. The deviation of $17 \%$ from the measurements is large, especially in relation to the total precipitation. This fact 
indicates that even if preferential flow exists, it is most likely not in the vertical direction and thus does not dominate the recharge in this type of soil. This is surprising since a network of macropores was visually observed in the soil profile. This may be due to the high water exchange rate between macropores and micropores in this sandy material, which restricted the role of macropore flow as it was observed in a similar sandy soil (Alaoui et al. 2003). Table 1 shows the high content of sand between 0.36 and $0.70 \mathrm{~m}(47-56 \%)$. Another explanation is that the reduced diameter of the macropores restricted the flow to a flow dominated by diffusion of capillary potential. Kätterer et al. (2001) noted a similar tendency for MACRO to overestimate water exchange between macropores and micropores when the soil was dry, which they attributed to water repellency in their organic-rich soil. Running the model under equilibrium conditions (excluding preferential flow) decreased the simulated recharge to $330 \mathrm{~mm}$, which exceeds measurements only by $5.4 \%$.

\section{Simulations in the topsoil}

The investigation of the topsoil between 0 and $0.70 \mathrm{~m}$ to estimate groundwater recharge yielded values of 364 and $394 \mathrm{~mm}$ under equilibrium and non-equilibrium conditions, respectively, which are only slightly higher in comparison with those obtained over the entire soil profile $(3 \mathrm{~m})$. Those values are acceptable when one considers the total recharge, but the response of the recharge to individual precipitation events is somewhat reduced due to an overly strong attenuation by the $2 \mathrm{~m}$ soil below the zero-flux plane (Fig. 6). In fact, recharge is normally hampered by thick alluvial soils, which allow high retention storage during the wet season and vegetation that subsequently extracts soil water in the following dry season. The finding that the total accumulated recharge was higher than the one observed, explains, in our case, some losses in the downward percolation and shows that not all this water necessarily reaches the water table. It might be hampered by low-conductivity horizons and disappear as interflow to nearby local depressions as suggested by de Vries and Simmers (2002). But the difference in our case is sufficiently small when compared to recharge derived from measurements and the result is considered satisfactory. Despite its successful application, this calibration method requires rapid measurements of soil moisture to reproduce the groundwater recharge and its temporal variations. Detailed field measurements are indispensable for recharge investigations, because they are the only means to realistically determine recharge processes (de Vries and Simmers 2002). Moreover, it is necessary to take into account the entire soil profile to visualize the fluctuation phenomena related to the recharge processes. These encouraging results show that the topsoil between 0 and $0.70 \mathrm{~m}$ plays the major role in the water balance. Our results indicate that the calibration using in situ moisture measurements during a brief infiltration run, is a simple but reasonably accurate method used in order to predict the groundwater recharge
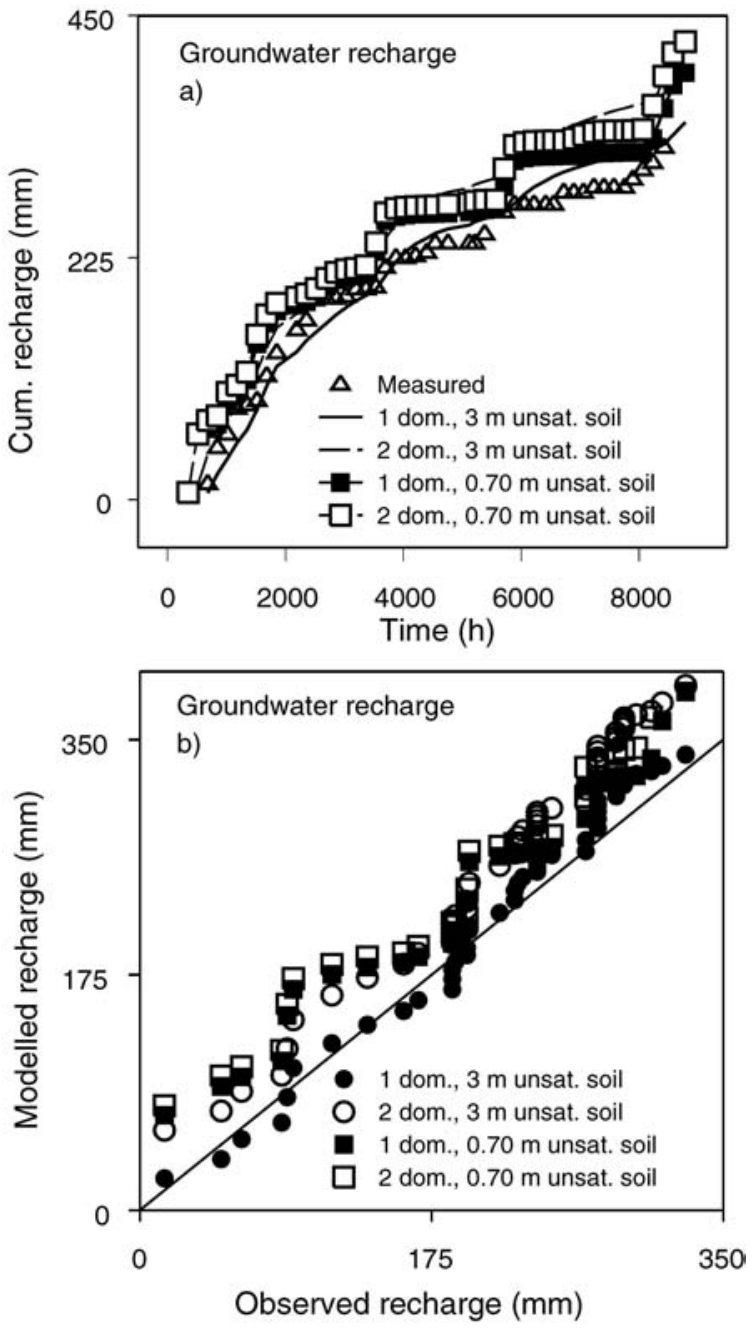

Fig. 6 Validation of the MACRO model with the groundwater recharge measurements: a cumulative recharge versus time, and $\mathbf{b}$ modeled versus observed recharge

through the topsoil under field conditions where the roots of the vegetation are active. In our case, this depth coincides with an interface which separates two distinctive textural horizons.

\section{Concluding Remarks}

It was demonstrated that the calibration of the MACRO model using rapid in situ water content measurements at several depths during and shortly after an artificial infiltration run of 2.8-h duration was sufficient to predict water content and total groundwater recharge over a period of one year. From these calibration data, the optimum model parameter set was extracted by an objective, automated algorithm.

The investigation of the topsoil above $0.70 \mathrm{~m}$ gave a satisfactory result in terms of total groundwater recharge, in comparison with both the value derived from the measurements and from simulations over the entire 
unsaturated soil. It was demonstrated using the refill gradients and textural investigations that at this depth $(0.70 \mathrm{~m})$, the zero-flux plane is localized, below which the water is no longer available for evapotranspiration and therefore directly contributes to recharging the groundwater body.

Additional knowledge of realistic ranges of some parameters such as the saturated hydraulic conductivity and the saturated water content was included as a boundary condition to improve the accuracy of the calibration.

For future applications, for example to investigate the heterogeneity of soil under homogeneous crop systems or to determine the subcatchment areas that contribute significantly to total recharge of a catchment, it is suggested that one should divide the basin into a certain number of representative plot classes and then conduct artificial in situ infiltration runs on each of them. For many cases, this might be sufficiently accurate. However, if recharge should be estimated over a limited area (e.g., for waste-disposal or local water-supplies), it is certainly necessary, in order to achieve a higher level of accuracy, to obtain additional information such as measured evapotranspiration and unsaturated hydraulic conductivity. Especially, the problem related to the spatial variability of evapotranspiration due to the diversity of plant types requires greater attention. To estimate evapotranspiration from a number of different cropping systems, micrometeorological measuring techniques or lysimeters may be necessary to provide the indispensable information on evapotranspiration rates of each plot class.

Acknowledgements This study was supported by the Swiss National Science Foundation, grant No. 21-36281.92. Werner Eugster received support from a Hans Sigrist Fellowship from the University of Bern. The first author would like to thank Nick Jarvis (Swedish University of Agricultural Sciences, Uppsala, Sweden) for his advice on modeling. The efforts of two anonymous reviewers helped to more clearly present our study.

\section{References}

Acutis M, Mdaghri-Alaoui A, Jarvis N, Donatelli M (2001) A software for sensitivity analysis, calibration and inversion of MACRO model. In: Proc. 2nd Int. Symp. on Modelling Cropping Systems, 16-17 July 2001, Florence, Italy, pp 207208

Alaoui A, Germann P, Jarvis N, Acutis M (2003) Dual-porosity and kinematic wave approaches to assess the degree of preferential flow in an unsaturated soil. Hydrol Sci J 48(3):455-472

Arnold JG, Williams JR, Nicks AD, Sammons NB (1989) SWRRB: a watershed scale model for soil and water resources management. In: Singh VP (ed) Computer models of watershed hydrology. Water Resources Publications, Highlands Ranch, Colorado, pp 847-908

Athavale RN, Murti CS, Chand R (1980) Estimation of recharge to the phreatic aquifers of the Lower Maner Basin, India, by using the tritium injection method. J Hydrol 45:148-168

Booltink HWG, Hatano R, Bouma J (1993) Measurement and simulation of bypass flow in a structured clay soil: a physicomorphological approach. J Hydrol 148:149-168
Brooks RH, Corey AT (1964) Hydraulic properties of porous media. Hydrology Paper No 3, Colorado State University, Fort Collins, Colorado, $27 \mathrm{pp}$

Burger A (1980) Etude de l'effet de l'épandage des boues d'épuration sur la nappe souterraine de la plaine d'Areuse [Investigation of the effect of sewage-sludge application on the groundwater body of the Areuse Plain]. Internal Report, Center of Hydrogeology, University of Neuchâtel, Switzerland

de Vries JJ, Simmers I (2002) Groundwater recharge: an overview of processes and challenges. Hydrogeol J 10:5-17

Duan Q, Gupta VK, Sorooshian S (1992) Effective and efficient global optimization for conceptual rainfall-runoff models. Water Resour Res 28(4):1015-1031

Edmunds WM, Gaye CB, Fontes JC (1992) A record of climatic and environmental change contained in interstitial water from the unsaturated zone of northern Senegal. In: Proc. Int. Symp. on isotope techniques in water resources developments, IAEA, Vienna, 1991, Publ IAEA-SM-319/35

Feddes RA, Bresler E, Neuman SP (1974) Field test of a modified numerical model for water uptake by root systems. Water Resour Res 10:1199-1206

Gerwitz A, Page ER (1974) An empirical mathematical model to describe plant root systems. J Appl Ecol 11:773-780

Hatton T (1998) Catchment scale recharge modelling: part 4 of the basics of recharge and discharge. CSIRO, Collingwood, Victoria

Jackson RB, Canadell J, Ehleringer JR, Mooney HA, Sala OE, Schulze E-D (1996) A global analysis of root distributions for terrestrial biomes. Oecologia 108:389-411

Jarvis N (1989) A simple empirical model of root water uptake. J Hydrol 107:57-72

Jarvis N, Leeds-Harrison PB (1990) Field test of a water balance model in cracking clay soils. J Hydrol 112:203-218

Jarvis N (1994) The MACRO model Version 3.1: technical description and sample simulations. Reports and Dissertations No 19, Department of Soil Science, Swedish University of Agricultural Sciences, Uppsala, Sweden, $51 \mathrm{pp}$

Kätterer T, Schmied B, Abbaspour KC, Schulin R (2001) Singleand dual-porosity modelling of multiple tracer transport through soil columns: effects of initial moisture and mode of application. Eur J Soil Sci 52:25-36

Klute A, Dirksen C (1986) Hydraulic conductivity and diffusivity: laboratory methods. In: Klute A (ed) Methods of soil analysis, 2nd edn. Part 1. Physical and mineralogical methods. , Am Soc Agron,Monogr 9, Madison, Wisconsin, pp 687-734

Lerner DN, Issar AS, Simmers I (1990) Groundwater recharge: a guide to understanding and estimating natural recharge. IAH vol 8. Heise, Hannover, 343 pp

Leavesley GH, Stannard LG (1995) The precipitation runoff modeling system: PRMS. In: Singh VP (ed) Computer models of watershed hydrology. Water Resources Publications, Highlands Ranch, Colorado, pp 281-310

Loague K, Green RE (1991) Statistical and graphical methods for evaluating solute transport models: overview and application. J Contamin Hydrol 7:51-73

Mdaghri-Alaoui A (1990) Hydrogeology of the Areuse plain: cartography of the water quality and evolution study of its variation in time-space scale [Hydrogéologie de la plaine d'Areuse: cartographie de la qualité de l'eau et étude de son évolution spatio-temporelle]. Dipl 3ème cycle, Centre for Hydrogeology, University of Neuchâtel, Switzerland

Mdaghri-Alaoui A, Müller I, Christe R (1993) Geophysical prospection in the Areuse delta (Switzerland): an application of the electro-magnetic VLF-resistivity multifrequency method [Prospection géophysique du delta de l'Areuse, Suisse. Application de la méthode électromagnétique VLF-Résistivité multifréquence]. Hydrogeol 1:47-52

Mdaghri-Alaoui A, Eugster W (2001) Field determination of the water balance of the Areuse river delta (Switzerland). Hydrol Sci J 46(5):747-760

Monteith JL, Unsworth MH (1990) Principles of environmental physics, 2nd edn. Arnold, London 
Mualem Y (1976) A new model for predicting the hydraulic conductivity of unsaturated porous media. Water Resour Res $12: 513-522$

Nulsen RA, Baxter IN (1986) Water use by some crops and pastures in the southern agricultural areas of Western Australia. Report No 32, Division of Resources Management, Western Australia Dept Agric, South Perth, Western Australia

Primault B (1962) On the calculation of the evapotranspiration [Du calcul de l'évapotranspiration], Arch Meteor Geophys B 12(1):124-150

Roth K, Schulin R, Flühler H, Attinger W (1990) Calibration of time domain reflectrometry for water content measurement using a composite dielectric approach. Water Resour Res 26:2267-2274

Rushton K, Ward RC (1979) The estimation of groundwater recharge. J Hydrol 41:343-362

Saxena RK, Jarvis NJ, Bergström L (1994) Interpreting non-steady state tracer breakthrough experiments in sand and clay soils using a dual-porosity model. J Hydrol 162:279-298

Singh VP (1995) Computer models of watershed hydrology. Water Resources Publications, Highlands Ranch, Colorado
Sophocleous MA (1991) Combining the soil water balance and the water-level fluctuation methods to estimate natural groundwater recharge: practical aspects. J Hydrol 124:229-241

Stephens DB (1994) A perspective on diffusive natural recharge mechanisms in areas of low precipitation. Soil Sci Soc Am J 58:40-48

Stephens DB (1996) Vadose zone hydrology. Lewis, Boca Raton, $339 \mathrm{pp}$

$\mathrm{Su}$ N (1994) A formula for computation of time-varying recharge of groundwater. J Hydrol 160:123-135

Van Tonder GJ, Kirchner J (1990) Estimation of natural groundwater recharge in the Karoo aquifers of South Africa. J Hydrol 121:395-419

Walker GR, Zhang L, Ellis TW, Hatton TJ, Petheram C (2002) Toward a predictive framework for estimating recharge under different land uses: review of modeling and other approaches. Hydrogeol J DOI 10.1001/s10040010181-5, 10:68-90

Zhang L, Dawes WR, Hatton TJ, Hume IH, O'Connell MG, Mitchell DC, Milthorp PL, Yee M (1999) Estimating episodic recharge under different crop/pasture rotations in the Mallee region, part 2: recharge control by agronomic practices. Agric Water Manage 42(2):237-249 